\title{
חHE SEA AS SITE OF MEMORY: THE DANISH SOUND AND THE DARDANELLES IN COMPARISON
}

\section{Michael North}

University of Greifswald, E-Mail: north@uni-greifswald.de

\section{Acknowledgments}

This paper has been presented at the Fourth International Conference on Nordic and Baltic Studies „Empire-building and Region-building in the Baltic, North and Black Sea Areas", in Constanta, Romania, May 24-26, 2013. Supported by a grant from Iceland, Liechtenstein and Norway (Finantat prin fonduri donate de Islanda, Liechtenstein si Norvegia)

\begin{abstract}
:
This paper introduces the concept of the sea as lieu de mémoire into maritime history. Pierre Nora has developed his "Lieux de mémoire" in France. According to Nora "a lieu de mémoire is any significant entity, whether material or non-material in nature [...] which has become a symbolic element of the memorial heritage of any community". Nora thus highlights symbolic values, hitherto often separated from historical sciences and reduced to historical narratives. In my paper I shall focus on shared memories, divided memories and entangled histories, but especially shared sites of memory. These - material or immaterial - "lieux de mémoire divisés" constitute symbolic intersections between cultures, spaces and times. They simultaneously affect not only the neighbouring countries and the national cultures of memory, but also societies and ethnic or religious groups. In two comparative case studies on the straits of the Sound (Oresund) and Dardanelles I shall try to test the application of the concept with respect to the various memories of the seafaring nations and ethnic communities, settling at the entrance of the Baltic Sea and the Black Sea.
\end{abstract}

\section{Rezumat:}

Această lucrare introduce în istoria maritimă conceptul de mare ca lieu de mémoire. Pierre Nora a dezvoltat conceptul său de "Lieux de mémoire" în Franța. In conformitate cu Nora, "un lieu de mémoire este orice entitate semnificativă, materială sau nematerială în natura sa [...], care a devenit un element simbolic al patrimoniului memoriei oricărei comunități". Nora subliniază, astfel, valori simbolice, anterior de multe ori separate de știința istorică și reduse la narațiuni istorice. In lucrarea mea mă voi concentra asupra unor memorii comune, memorii 
divizate și istorii împărtășite, dar în special asupra unor toposuri comune de memorie. Aceste "lieux de mémoire divisés" - materiale sau imateriale - constituie intersecții simbolice între culturi, spații și timp. Acestea afectează în același timp nu numai țările vecine și culturile naționale de memorie, dar, de asemenea, societățile și grupurile etnice sau religioase. In cadrul a două studii de caz comparative privind strâmtorile Sound (Oresund) și Dardanele voi încerca să testez aplicarea conceptului cu privire la diversele aspecte ale memoriei națiunilor din sectorul maritim și comunităților etnice stabilite la intrarea în Marea Baltică și Marea Neagră.

Keywords: Sound; Oresund; Dardanelles; Baltic Sea; Black Sea; Memory

\section{Introduction}

This paper introduces the concept of the sea as lieu de mémoire into maritime history. Instead of reconstructing the representation of the sea in the literature (Herman Melville, Moby Dick), art (marine paintings) and music (Claude Debussy, La Mer), I would like to discuss broader concepts that have been conceptualized and require international and interdisciplinary collaboration.

Scrutinizing the sea as a global, historical phenomenon exceeds a mere investigation of its representation in the fine arts. Since biological, economic, social, cultural, political, religious, national and transnational aspects are involved, a broader concept such as the sea as a global lieu de mémoire could overcome the traditional limitations of individual disciplines.

The first scholars who introduced this new approach a few years ago were literature specialists by deconstructing the mythical view of the sea "as a symbol of madness, irrational femininity, unruly or romantic anticivilization" (in contrast to the construction of a rational "landed" modernity). ${ }^{1}$

By "historicizing the ocean," these colleagues endeavoured to deconstruct the prevailing views of maritime encounters at sea and thereby transcended the nation state as well as traditional maritime history. One of the path breaking books of this kind was Paul Gilroy's „Black Atlantic“. ${ }^{2}$ The

\footnotetext{
${ }^{1}$ Bernhard Klein and Gesa Mackenthun, „Introduction. The Sea is History,“ in: Bernhard Klein and Gesa Mackenthun, eds., Sea Changes: Historicizing the Ocean (New York 2004), 2. 2 Paul Gilroy, The Black Atlantic: Modernity and Double-Consciousness (Cambridge 1993), 17. 66
} 
Black Atlantic can be defined as a specific modern trans-cultural entity, represented and at the same time largely constituted by the sailing ship as a "living micro-cultural, micro-political system in motion".

Oceans and ships are thus assessed as spaces and sites of cultural conflict as well as of cooperation. Others such as Marcus Rediker perceive the ocean as a virtual „Red Atlantic“, a maritime space of revolutionary dynamics, emerging capitalism, exploitation and repression, violence and resistance (an Atlantic Ocean of workers). ${ }^{3}$

Interestingly, the concept of memory is only implicitly or indirectly addressed by these approaches, but does not play a more substantial role. That is why a concept of the sea as lieu mémoire still offers more scientific potential.

To begin with, I would like to introduce the concept of lieux de mémoire, and then extend this concept to the sea as lieu de mémoire and end with a few case studies related to the Baltic Sea and the Black Sea.

\section{The concept of lieux de mémoire}

The concept of lieux de mémoire was developed (as you all know) in France by Pierre Nora. France is unique with respect to collective memory, since state, nation and history are indissolubly. This situation stimulated the edition of a monumental work of seven volumes "Les lieux de mémoire“ (1984-92). ${ }^{4}$ According to Nora "a lieu de mèmoire is any significant entity, whether material or non-material in nature ... which has become a symbolic element of the memorial heritage of any community (in this case the French community) “. ${ }^{5}$ Nora thus highlights symbolic values, hitherto often separated from historical sciences and reduced to historical narrative (since they constitute an integral, often unseparable part of history). Sites of memory are

- places such as archives, museums, cathedrals, castles, cemeteries etc.

\footnotetext{
${ }^{3}$ Marcus Rediker, "The Red Atlantic, or, 'a terrible blast swept over the heaving sea'," in: Bernhard Klein and Gesa Mackenthun, eds., Sea Changes: Historicizing the Ocean (New York 2003), 111-130; Peter Linebaugh and Marcus Rediker, The Many-Headed Hydra: Sailors, Slaves, Commoners, and the Hidden History of the Revolutionary Atlantic (Boston 2000).

4 Pierre Nora, ed., Les lieux de mémoire, 7 vol. (Paris 1983-92).

${ }^{5}$ Pierre Nora, „From lieux de mémoire to realms of memory," in: Pierre Nora and Lawrence D. Kritzman, eds., Realms of Memory: Rethinking the French Past. Vol. 1: Conflicts and Divisions (New York 1996), XV-XXIV.
} 
- concepts and practices such as commemorations, generations, mottos, rituals

- objects such as inherited property, monuments, manuals, emblems, basic texts, symbols. ${ }^{6}$

Pierre Nora started his research on selected places of the French national heritage, and only gradually a new form of (symbolic) historiography developed. This new historiography emerged in the third volume (under the significant title Les France) and encompassed, according to Nora, "many voices" that suit the scientific and social demands of our time better than the "classical historiography". The concept of lieux de mémoire contributes to the development of a history of symbols or symbolic meanings respectively and to the construction of a "symbolic topology" of France. The lieux de mémoire thus define France as a symbolic reality and reflect the Grande Nation. Also in the subsequent projects on Italy, Germany, Austria, Denmark and the Netherlands the "Erinnerungsorte“ or "plaatsen van herinnering" are related to or better define the cultural memory of the nation or nation states. ${ }^{7}$ As memories in general are selective, the cultural or national memories are even more subject to selection. ${ }^{8}$ So the Dutch „plaatsen van herinnering" recorded only places and monuments in the narrow sense, whereas the German "Erinnerungsorte“ include also abstract objects of remembrance such as the Reformation, the German Mark, the Bundesliga etc.

Due to the dominating national perspective, at first glance, the lieux de mémoire seem to oppose the demands of a transnational concept of the sea. At this juncture, however, lie the challenges and perspectives of this concept.

\footnotetext{
6 Ibid.

7 Maarten Prak, Plaatsen van herinnering Nederland in de zeventiende en achttiende eeuw, Amsterdam 2006; Wim Blockmans and Herman Pleij, eds., Plaatsen van herinnering. Deel I: Nederland van prehistorie tot Beeldenstorm (Amsterdam 2007); Jan Bank, Nederland in de negentiende eeuw (Amsterdam 2006); Hagen Schulze and Étienne François, eds., Deutsche Erinnerungsorte. Eine Auswahl. 3 Vols. (München 2005); Mario Isnenghi, ed., I luoghi della memoria. 3 Vols. (Rom/Bari 1997/98); Ole Feldbaek, ed., Dansk identitatshistorie (København 1991/92); Moritz Csaky, ed., Die Verortung von Gedächtnis (Wien 2001); Sonja Kmec, Benoît Majerus, Michel Margue and Pit Peporte, eds., Lieux de mémorie au Luxembourg, Erinnerungsorte in Luxemburg (Luxemburg 2007).

8 Elizabeth Hallam and Jenny Hockey, Death, Memory and Material Culture (Oxford 2001); Johannes Fried, Der Schleier der Erinnerung. Grundzüge einer historischen Memorik (München 2004).

68
} 
Like conceptualizing the ocean, a transnational extension of the lieux de mémoire-concept will provide a tool for the study of maritime representation. A first step has already been made in this direction by publishing a selection of the "Mémoires allemandes" through the publishers Beck and Gallimard in France, and the "Erinnerungsorte Frankreichs" in Germany. ${ }^{9}$ The idea was to show the entanglement of histories and memories of France and Germany by an intensive collaboration of French and German historians (Etienne François). ${ }^{10}$

However, all over Europe and outside Europe as well we witness entangled memories. Even if most memories and often also the realms of memory are perceived by a national prisma, they are influenced and constituted by a trans-national perspective. That is why future research has to focus on shared memories respectively divided memories (memoria divisa) and entangled histories, especially shared realms of memory. These - material or immaterial - lieux de mémoire divisés constitute symbolic intersections between cultures, spaces and times. They simultaneously affect the neighbouring countries and the national cultures of memory, but societies and ethnic or religious groups as well. ${ }^{11}$ The sea provides an excellent example and object of study for this category of shared realms of memory, lieux de mémoire divisés.

It is, however, worthwhile to divide the category "sea" into subcategories such as oceans and seas that all constitute lieux de mémoire divisés and provide a framework for entangled histories. Narrowing it further down, we could investigate coastal lines, straits but also naval battles and shipwrecks.

In my case study, I would like to examine straits such as the Sound (Danish: Øresund, Swedish: Öresund) and the Dardanelles, which have great a potential as lieux de mémoire. Coming from the Baltic Sea, I will focus on the Sound, the strait which separates the Danish island Zealand (Sjælland) from the south Swedish province Scania (Skåne) that used to

\footnotetext{
${ }^{9}$ Étienne François and Hagen Schulze, eds., Mémoires allemandes (Paris 2007); Pierre Nora, ed., Erinnerungsorte Frankreichs (München 2005).

10 Étienne François, „Pierre Nora und die «Lieux de mémoire»," in: Pierre Nora, ed., Erinnerungsorte Frankreichs (München 2005), 7-14, here 14.

11 Ann Rigney, "Divided Pasts: A Premature Memorial and the Dynamics of Collective Remembrance," Memory Studies, 1 (2008): 89-97; Idem., The Afterlives of Walter Scott. Memory on the Move (Oxford 2012).
} 
belong to Denmark until 1658 and compare it with the Straits of the Dardanelles.

\section{Case studies: The Sound and the Straits of Dardanelles}

The Sound was and still is the gateway from the Baltic to the North Sea and the Atlantic Ocean and constitutes one of the busiest waterways of the world. The entrance into and the exit from the Baltic has been guarded by the castle of Kronborg at Elsinore (Helsingør) located at a place, where the strait is only 4 kilometres wide.

Since King Erik introduced the Sound Toll in 1429, ships passing through the strait had first to pay one golden Noble and later a 1-2 \% tax of the cargo value. The income from the Sound Toll was a most important source of income for the Danish ground and financed the ambitious building programme of the Danish kings in Copenhagen and Zealand including the castle of Kronborg. The Sound Toll registers have been object of extensive research by maritime historians and historians of commerce since the early $20^{\text {th }}$ century. ${ }^{12}$

\footnotetext{
12 Nina E. Bang and K. Korst, Tabeller over skibsfart og vaeretransport gennem Oeresund 14971783 [7 volumes] (Copenhagen/Leipzig 1906-1953); P. de Buck and J.Th. Lindblad, „De scheepvaart en handel uit de Oostzee op Amsterdam en de Republiek," Tijdschrift voor Geschiedenis, 96 (1983): 526-562; A. E. Christensen, „Der handelsgeschichtliche Wert der Sundzollregister. Ein Beitrag zur seiner Beurteilung," Hansische Geschichtsblätter, 59 (1934): 28142; A. E. Christensen, Dutch trade to the Baltic around 1600 (Copenhagen/The Hague 1941); P. Jeannin, „Les comptes du Sund comme source pour la construction d'indices généraux de l'activité économique en Europe (XVIe-XVIIIe siècle)," Revue Historique, 231 (1964): 55-102, 307-340 ; W. S. Unger, „De Sonttabellen," Tijdschrift voor Geschiedenis, 41 (1926): 137-155. 
Graphic „Number of ships cleared in the Danish Sound, 1503-1845“13

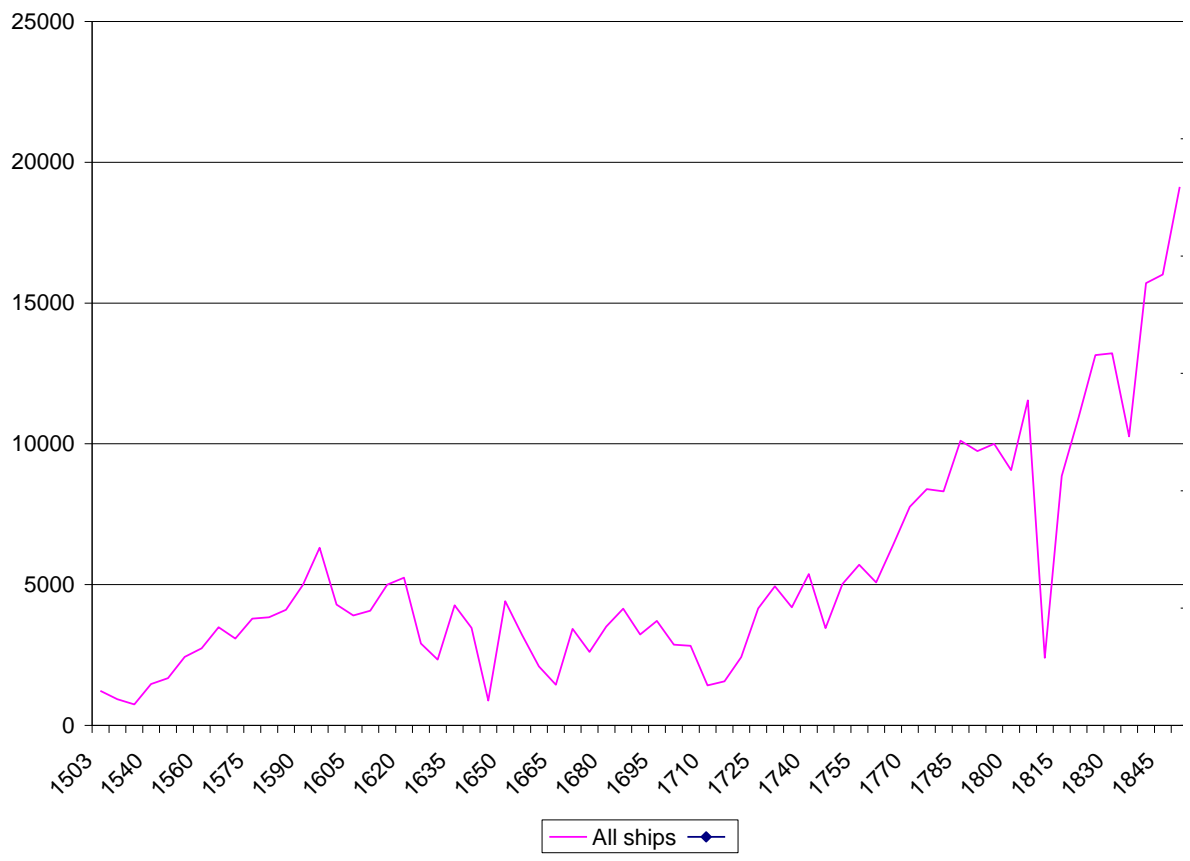

Ships of all nations sailed via the Sound rendering this strait a place of shared memory for all seafaring nations. However, the Dutch and later the Scandinavians dominated the other trading-nations. Since Denmark used this location to control the entrance to the Baltic Sea, Kronborg and the Sound became object of long lasting struggles about the dominium maris baltici, between Denmark, Sweden, Poland and Russia, whereby the Dutch and the English entered into different coalitions with the seafaring powers in the Baltic.

In the $16^{\text {th }}$ century Lübeck's fleet attacked Elsinore for several times, and during the $17^{\text {th }}$ century Sweden and Denmark were constantly in state of war at the entrance to the Baltic Sea especially on the domination of Scania (Skåne). The Dutch, the major maritime and commercial power, intervened on both sides to secure the undisturbed entry to its trading area. In 1644 the Dutch fleet sailed unhindered trough the Sound and joined the Swedish fleet

\footnotetext{
13 Presentation by Jari Ojala, "Research potential of the database and guidebooks" for the conference „Baltic connections,“ Denmark 29-31 October 2007; Peter Borschberg and Michael North, "Transcending Borders: The Sea as Realm of Memory," Asia Europe Journal, 8(3) (2010): 279-292.
} 
to defeats the Danes. The background for this Swedish-Dutch alliance was Christian IV's attempt to raise the Sound Toll dues. In 1657/58 the Dutch, however, regarded the prospect of Sweden dominating the Sound as equally devastating to their mercantile power. Nevertheless, Scania finally became Swedish in 1658.

Only after the Russian-Danish victory in Great Northern War (1721) Denmark enjoyed a long period of peace thanks to its neutrality. The maritime traffic through the Sound rose tremendously around 1750, when between 4,000 and 5,000 ships had to pay their Sound Dues annually, and the numbers of ships continued to rise. Captains became increasingly dependent on consuls and customs agents for the arrangement of declaring cargoes and calculating the various tariffs. In exchange for the consuls' or agents' assistance the captains bought the provisions from them.

The Straits of Dardanelles was subject of continuous struggles as well. From the Trojan War in the thirteenth century B. C. the control of the Hellespont was crucial for troy that forced Greek sailors to halt there and profited from the rich Black Sea trade. ${ }^{14}$ With the Greek victory in the Trojan War the control of the straits and unlimited shipping to the Black Sea was vital for Greek merchants and the expansion of trade. The foundation of Constantinople in 330 followed late roman strategic and political interests in the region. The city, a melting pot of Greek, Roman and oriental cultures however was challenged by the Italian trading cities Pisa, Genoa and Venice (11 ${ }^{\text {th }}$ century), which did not only trade in Byzantium, but demanded a free passage to the ports of the Black Sea. The struggle for Constantinople, occupied by the Venetians 1204 to 1261, was at the same time a struggle of the Dominium of the Black Sea. Here Genoa had established the colony of Caffa as an emporium of slaves, sugar and oriental products. The situation changed with the Ottoman expansion, when Suleiman seized and fortified Gallipoli in 1356. Now the Ottoman Turks had fortifications on both sides of the Dardanelles, 1.5 kilometres in widths.

Although Constantinople still defended itself, Genoa and Venice achieved the concession of the free passage through the Dardanelles from the Turks. After the fall of Constantinople the Turks established a new

\footnotetext{
${ }_{14}$ Good overview of the following James T. Shotwell and Francis Deák, Turkey at the Straits. A Short History (New York 1971), 1-31. 
control of the straits at the Bosphorus and gradually excluded Christian shipping from the Black Sea, thus ending the Genoese colony at Caffa as well.

The expansion of the Ottoman Empire meant not only the control of the Black Sea, but also of the Eastern Mediterranean. Traders with the Black Sea Ports and the Levant had to rely on concessions, granting extraterritorial jurisdiction to consuls and conceding special privileges. France was the first obtain a so-called capitulation in 1535, followed by England 1579 and the Netherlands 1598 and 1612. Thus the Dardanelles were opened again and ships could reach Constantinople after stopping at the castle of Gallipoli. Since European shipping on the Black Sea was still prohibited, European traders had to charter Turkish ships.

Nevertheless the conflict between Venice and the Ottoman Empire continued throughout the $17^{\text {th }}$ century, as Venice tried to defend her remaining possessions in the Eastern Mediterranean, such as Crete, Venice's largest and richest overseas territory, against the Turkish expansion. To hamper the Ottoman navy, the Venetian annually blocked the Dardanelles. This led to a number of Veneto-Turkish Dardanelles Battles in the mid-17th century. Since the Venetian ships were equipped with Dutch and English sailors, the battles entered into the European visual memory. ${ }^{15}$

The 1680s saw the defeat of the Turks at Vienna, the Turkish loss of Greek ports such as Morea and the beginning of the Russian expansion to the Black Sea. Although campaign of Peter the Great against Azof was successful, the Turks prevented that Russian ships sailed out of the Sea of Azof and that Russian goods were shipped across the Black Sea to Constantinople. Only Catherine the Great was able to conquer the Northern Black Sea coast for Russia. To achieve this aim she had to send the Russian Baltic fleet around Gibraltar in 1770 to blockade the Dardanelles and to reach Constantinople from the West. This attempt was only partially successful. It ended, however, the Turkish monopoly of shipping in the Straits and the Black Sea. The Treaty of Kutchuk-Kainardji (1774) between Turkey and Russia declared „free and unimpeded navigation for the merchant ships belonging to the two Contracting Powers" ${ }^{\text {" }}{ }^{16}$

Other European powers followed and gained free passage for the merchants ships (Austria 1784, England 1799, France 1802, Prussia 1806).

\footnotetext{
${ }^{15}$ David S. T. Blackmore, Warfare on the Mediterranean in the Age of Sail. A History, 1571-1866 (North Carolina and London 2011), 91-94, 103-105.

16 Shotwell/Deák, Turkey at the Straits, 21.
} 
Although the Turkish monopoly was broken with respect to merchants ships, Turkey still controlled and prohibited the passage of war-ships. In this regard during the Napoleonic era France, Russia and England struggled for the Turkish ally. Thus a British fleet forced the Dardanelles in 1807 and invaded Constantinople after Turkey had sided with France. Britain became de facto guardian of the Straits almost as much as Turkey.

Many mercantile nations were present at the Dardanelles as at other straits like the Danish Sound. Apart from merchant communities consuls played an important role. The consuls were the precursors of the diplomatic missions and closely related to trade. When the Ottoman Empire granted the so-called "Capitulations" as privileges of residence and trade for nonMoslems, the expansion of trade was often followed by the opening of consulates at the Dardanelles and Gallipoli. Whilst Genoese and Venetian representatives were already present in late $15^{\text {th }}$ century. Consuls from France 1535, England 1580, Netherlands (Holland) 1598, 1612, Austria 1718, Sweden 1736/1737, Kingdom of the two Sicilies 1740, Tuscany, Hamburg \& Lübeck 1747, Denmark 1756, Prussia 1761, Spain 1782, Russia 1717/1783, Sardinia c. 1825, USA 1830, Belgium 1839, Hanseatic towns 1839?, Portugal 1843, Greece 1855 and Brazil 1858 followed. At the beginning a crucial role was played by the Jewish merchants who represented at the same time different European trading interests. It was often common that a consul was at the same time the representative of the Netherlands and France or of the Netherlands and England. Apart from the Jewish families the so-called Dragoman dynasties were also crucial in the Ottoman Empire. They were subjects of the Ottoman Empire, where they had been settled for centuries. Attached to the embassies they worked as translators and created family networks of trust in the Levant. Famous Dragoman families like the Chabert (Sardinia), the Fonton (Russia, Denmark, Sweden and Norway) or the Fornetti (France) were crucial in smoothening different trading interests and avoiding trading conflicts at the Dardanelles. ${ }^{17}$

The visual heritage of the consulates is still present, but deserves as the consular reports further investigation.

Elsinore at the Danish Sound was also a multicultural city. While in the $17^{\text {th }}$ century Elsinore resembled "Little Amsterdam,“ in the $18^{\text {th }}$ century,

\footnotetext{
17 Collaborative online research project "Consuls of "The Dardanelles" and "Gallipoli", www.levantineheritage.com/pdf/Consuls_of_the_Dardanelles.pdf, updated Version no: 4 February 2013. 
due to the growing English trade to the Baltic, an increasing number of English merchants settled at the Sound. In many cases the family business was successfully carried out and handed over from generation to generation. The merchants built splendid houses and warehouses in the heart of Elsinore close to the waterfront, many of which still exist. Some of these prosperous English merchants also acquired country estates to retire to during summertime, and of course they gave them suitable English names, such as "Fairyhill“ or "Claythorpe". These English families did little to endear themselves to the townsfolk of Elsinore, who often regarded them as unspeakably arrogant. When members of these families died they were buried in Elsinore Cemetery, but their gravestones were especially ordered from England. Many of them have survived.18

The Battle of Copenhagen (1801) and the Bombardment of Copenhagen (1807) forced merchants, consuls and agents out of business, but after 1815 the traffic recovered. Even smaller nations now sent several hundred ships per year via the Sound to the West.

The passage through the Sound was not only recorded by the Sound Toll registers, but also by painters that provided every captain with a painted snapshot of his ship, a standardised captain's picture.

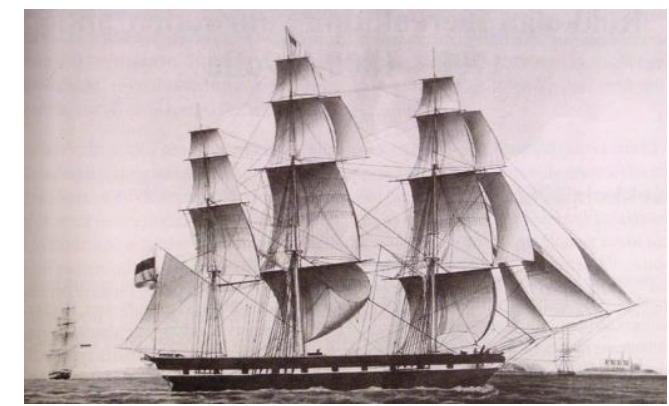

Ship Adonis, mid-1830s (Ojala 1997/GSF)

\footnotetext{
18 David Hohnen, Hamlet's Castle Hamlet's Castle and Shakespeare's Elsinore (Copenhagen 2000), 102-105.
} 


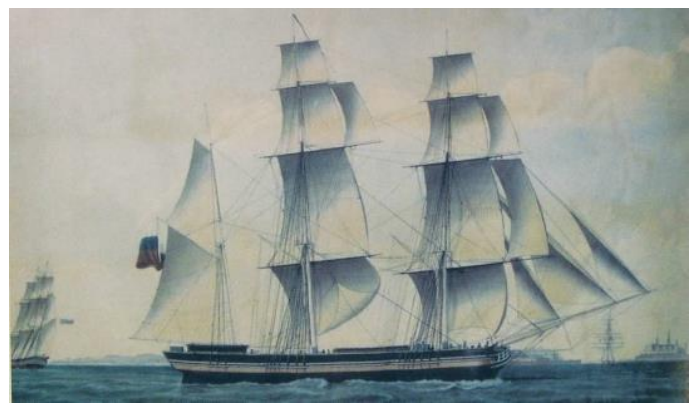

Barque Sovio (Raahe), 1860 (RM/ Raahen historia)

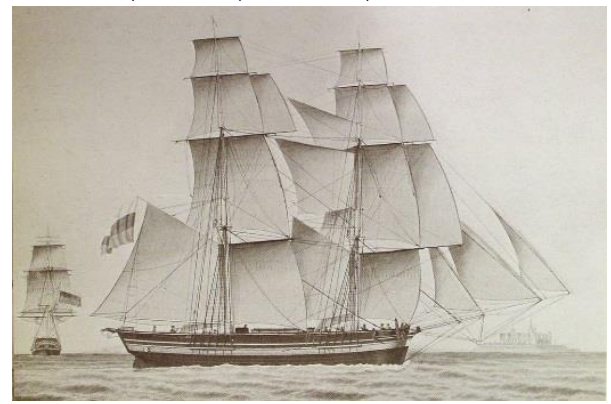

Phoenix, Oulu 1827 (Snellman, Oulun laivoja ja laivureita...)

These Finnish examples date from the 1860s, when the Sound was perceived in a mere cultural perspective. Since the USA had refused to pay the Sound Dues from the 1850s, an international agreement brought the Sound Toll to its end. As a compensation 35,000,000 rix-dollars were paid to Denmark by all maritime nations, trading with the Baltic. Nevertheless at least for the Scandinavians the Sound as a gateway to the West was and still is a lieu de mémoire. Numerous paintings recorded Kronborg and the Sound.

As regards the Dardanelles, the cultural perspective is only one, since Russian-Turkish conflicts put the Dardanelles question on the European diplomatic agenda. After the Ottoman defeat in the Russo-Turkish War of 1828-29, Russia put pressure on the Ottoman Empire in the Treaty of Hunkiar Iskelesi to act as guardian of the straits on behalf of Russia. As a result the alarmed Western Powers reached an agreement in the London Straits Convention in July 1841 that only Turkish war-ships could pass through the Dardanelles in peacetime. As allies of the Ottoman Empire during the Crimean War in 1854 France and Britain sent war-ships through the straits. The convention of 1856 more or less confirmed the convention of 1841. Attempts to demilitarize and to remilitarize the straits after the First World War and Greco-Turkish War (1919-1922) ended up in the settlement 
of Montreux (Montreux convention of July 1936). According to the convention the straits is an international shipping route, but Turkey has the right to restrict the naval traffic of non-Black Sea nations (like Greece). This settlement has not been challenged in the $20^{\text {th }}$ and $21^{\text {st }}$ centuries. The $20^{\text {th }}$ century memory of the straits, however, has been overshadowed by the battle of Gallipoli, where a British, Indian, Australian and New Zealand intervention force tried to open the straits in 1915. With more than 200,000 casualties on both sides the British defeat created a special memory which is celebrated as ANZAC-Day in Australia and New Zealand until today.

However, by building the Øresund Bridge, inaugurated on July 1, 2000 by King Carl XVI. Gustav of Sweden and Queen Margrethe II. of Denmark, the meaning of the Sound has changed again. People of Copenhagen are again moving to Scania, where they find affordable housing, and the Swedish from Scania commute for work to Denmark (14,000 people commuting every day over the Øresund Bridge). With the opening of the bridge politicians tried to create an "Øresund identity" to overcome old Dano-Swedish stereotypes. One step in this direction was the foundation of the Øresund University, a consortium of twelve universities (four Swedish and eight Danish) from both sides of the Sound, which established joint courses, libraries and other facilities to all students, teachers and researchers from the region.

\section{Conclusion}

This case study on the Sound and the Straits of Dardanelles unveils the fact, that the extension of the concept of lieux de mémoire to the sea, especially to maritime regions might be a productive tool of examining maritime history after the cultural turn. The international comparative perspective of national and regional maritime histories is one of the leading tasks of the future. Hereby entangled maritime cultures and the shared or divided memories deserve closer examination.

\section{References:}

\section{A. Books, articles, published documents:}

Bang, Nina E./Korst, K., Tabeller over skibsfart og vaeretransport gennem Oeresund 1497-1783 [7 volumes] (Copenhagen/Leipzig 1906-1953). 
Bank, Jan, Nederland in de negentiende eeuw (Amsterdam 2006).

Blackmore, David S. T., Warfare on the Mediterranean in the Age of Sail. A History, 1571-1866 (North Carolina and London 2011), 91-94, 103105.

Blockmans, Wim/Pleij, Herman, eds., Plaatsen van herinnering. Deel I: Nederland van prehistorie tot Beeldenstorm (Amsterdam 2007).

Borschberg, Peter/North, Michael, "Transcending Borders: The Sea as Realm of Memory," Asia Europe Journal, 8(3) (2010): 279-292.

Buck, P. De/Lindblad, J. Th., „De scheepvaart en handel uit de Oostzee op Amsterdam en de Republiek," Tijdschrift voor Geschiedenis, 96 (1983): 526-562.

Christensen, A. E., „Der handelsgeschichtliche Wert der Sundzollregister. Ein Beitrag zur seiner Beurteilung," Hansische Geschichtsblätter, 59 (1934): 28-142.

Christensen, A. E., Dutch trade to the Baltic around 1600 (Copenhagen/The Hague 1941).

Csaky, Moritz, ed., Die Verortung von Gedächtnis (Wien 2001).

Feldbaek, Ole, ed., Dansk identitatshistorie (København 1991/92).

François, Étienne, „Pierre Nora und die «Lieux de mémoire», " in: Pierre Nora, ed., Erinnerungsorte Frankreichs (München 2005), 7-14, here 14.

François, Étienne/ Schulze, Hagen, eds., Mémoires allemandes (Paris 2007).

Fried, Johannes, Der Schleier der Erinnerung. Grundzüge einer historischen Memorik (München 2004).

Gilroy, Paul, The Black Atlantic: Modernity and Double-Consciousness (Cambridge 1993).

Hallam, Elizabeth/Hockey, Jenny, Death, Memory and Material Culture (Oxford 2001).

Hohnen, David, Hamlet's Castle Hamlet's Castle and Shakespeare's Elsinore (Copenhagen 2000), 102-105.

Isnenghi, Mario, ed., I luoghi della memoria. 3 Vols. (Rom/Bari 1997/98).

Jeannin, P., „Les comptes du Sund comme source pour la construction d'indices généraux de l'activité économique en Europe (XVIe-XVIIIe siècle), "e Revue Historique, 231 (1964): 55-102, 307-340.

Klein, Bernhard/Mackenthun, Gesa, "Introduction. The Sea is History,“ in: Bernhard Klein and Gesa Mackenthun, eds., Sea Changes: Historicizing the Ocean (New York 2004). 
Kmec, Sonja/Majerus, Benoît/Margue, Michel/Peporte, Pit, eds., Lieux de mémorie au Luxembourg, Erinnerungsorte in Luxemburg (Luxemburg 2007).

Linebaugh, Peter/Rediker, Marcus, The Many-Headed Hydra: Sailors, Slaves, Commoners, and the Hidden History of the Revolutionary Atlantic (Boston 2000).

Nora, Pierre, „From lieux de mémoire to realms of memory,“ in: Pierre Nora and Lawrence D. Kritzman, eds., Realms of Memory: Rethinking the French Past. Vol. 1: Conflicts and Divisions (New York 1996), pp. XVXXIV.

Nora, Pierre, ed., Erinnerungsorte Frankreichs (München 2005).

Nora, Pierre, ed., Les lieux de mémoire, 7 vol. (Paris 1983-92).

North, Michael, Geschichte der Ostsee. Handel und Kulturen. Munich 2011.

Prak, Maarten, Plaatsen van herinnering Nederland in de zeventiende en achttiende eeuw, Amsterdam 2006.

Rediker, Marcus „The Red Atlantic, or, 'a terrible blast swept over the heaving sea'," in: Bernhard Klein and Gesa Mackenthun, eds., Sea Changes: Historicizing the Ocean (New York 2003), 111-130.

Rigney, Ann, „Divided Pasts: A Premature Memorial and the Dynamics of Collective Remembrance," Memory Studies, 1 (2008): 89-97.

Rigney, Ann, The Afterlives of Walter Scott. Memory on the Move (Oxford 2012).

Schulze, Hagen/ François, Étienne, eds., Deutsche Erinnerungsorte. Eine Auswahl. 3 Vols. (München 2005).

Shotwell, James T./ Deák, Francis, Turkey at the Straits. A Short History (New York 1971), 1-31.

Unger, W. S., „De Sonttabellen, “ Tijdschrift voor Geschiedenis, 41 (1926): 137155.

\section{B. Web postings:}

Collaborative online research project "Consuls of "The Dardanelles" and "Gallipoli", www.levantineheritage.com/pdf/Consuls_of_the_Dardanelles.pdf, updated Version no: 4 February 2013. 